Original Research Article

\title{
Genotoxic evaluation of ceftriaxone by in vivo micronucleus test in albino mice
}

\author{
Kunjumon Dayana ${ }^{1}$, Megaravalli R. Manasa ${ }^{2 *}$
}

${ }^{1}$ Department of Pharmacology, Pushpagiri Institute of Medical Sciences and Research Centre, Thiruvalla, Kerala, India ${ }^{2}$ Department of Pharmacology, Karwar Institute of Medical Sciences, Karwar, Karnataka, India

Received: 12 August 2018

Accepted: 18 August 2018

\section{*Correspondence to:}

Dr. Megaravalli R. Manasa, Email: dr.manasamr@ gmail.com

Copyright: (C) the author(s), publisher and licensee Medip Academy. This is an openaccess article distributed under the terms of the Creative Commons Attribution NonCommercial License, which permits unrestricted noncommercial use, distribution, and reproduction in any medium, provided the original work is properly cited.

\begin{abstract}
Background: Genotoxicity screening of drugs is essential. It is mandatory for new drugs. However, screening of drugs already in use is also necessary. Several cephalosporins are reported to induce chromosomal aberrations in previous studies. But there is paucity of data regarding the genotoxic potential of ceftriaxone. Hence the present study was undertaken to evaluate the genotoxic potential of ceftriaxone, a third generation cephalosporin, by micronucleus assay in albino mice.
\end{abstract}

Methods: In vivo micronucleus test was performed with mice bone marrow after intraperitoneal injection of ceftriaxone at $100 \mathrm{mg} / \mathrm{kg} \mathrm{BW}$ and $200 \mathrm{mg} / \mathrm{kg} \mathrm{BW}$ at 24 $\mathrm{hr}$ and $48 \mathrm{hr}$ harvest time. Mice bone marrow was harvested, and slides were prepared. The percentage of micronucleated polychromatic erythrocytes (\% MnPCE) and the ratio of polychromatic erythrocytes to normochromatic erythrocytes (PCE:NCE) were determined. The data from ceftriaxone treated groups was compared with control group and analyzed using ANOVA followed by Dunnett's test.

Results: Ceftriaxone at the dose of $100 \mathrm{mg} / \mathrm{kg} \mathrm{BW}$ and $200 \mathrm{mg} / \mathrm{kg}$ BW did not exhibit any significant increase in the percentage of micronucleated polychromatic erythrocytes. It also did not decrease the ratio of polychromatic erythrocytes to normochromatic erythrocytes significantly.

Conclusions: The present study demonstrates that ceftriaxone is not genotoxic in in vivo micronucleus study in albino mice at a dose of $100 \mathrm{mg} / \mathrm{kg} \mathrm{BW}$ and $200 \mathrm{mg} / \mathrm{kg} \mathrm{BW}$.

Keywords: Ceftriaxone, Genotoxicity, Micronucleus test, Mice

\section{INTRODUCTION}

Cephalosporins are widely used antibiotics. They are active against a wide range of gram positive and gram negative bacteria. Ceftriaxone is a third generation cephalosporin which is commonly used because of its enhanced efficacy and safety profile. It has high efficacy in a number of bacterial infections like bacterial meningitis, complicated urinary tract infections, multiresistant typhoid fever, abdominal sepsis and septicaemias. Allergic reactions and bleeding are the common adverse reactions caused by ceftriaxone..$^{1-3}$

Recently, it has been realized that genotoxicity screening of drugs is important. New molecules are tested for genotoxicity before they are released for clinical use. ${ }^{4-6}$ Several genotoxicity tests such as Ames test, micronucleus test, comet assay and test for choromosomal aberrations in human lymphocytes cultured in vitro are available. Among them, the in vivo rodent micronucleus test is one of the primary genotoxicity assays recommended by regulatory agencies internationally. ${ }^{7}$ 
The screening of old drugs which are already available for clinical use is also essential. In previous studies, it has been reported that several antibiotics especially the cephalosporins like cefixime, cefaclor, cefadroxil, cefotaxime induce chromosomal aberrations. ${ }^{8,9}$ However, there is paucity of reports regarding the genotoxic potential of ceftriaxone. Since ceftriaxone is commonly used drug, it is prudent to screen it for genotoxicity. Hence, the present study was undertaken to evaluate the mutagenic and genotoxic potential of ceftriaxone in albino mice by micronucleus test.

\section{METHODS}

\section{Chemicals}

Ceftriaxone and other biochemical compounds such as giemsa stain, fetal bovine serum, May - Grunwald stain were obtained from Sigma - Aldrich chemicals Pvt. Ltd., Bangalore, India. All other chemicals and solvents used were of analar grade.

\section{Animals}

Albino mice of either sex, 7 to 8 weeks of age and weighing 32-40g were used for the present study. The animals were obtained from central animal house, Sri Kaliswari college, Sivakasi, India. They were housed in poly propylene cages with 12 hours light and 12 hours dark cycles. The animals were randomized into experimental and control groups and housed 4 or 5 per cage. Standard pellets were used as a basal diet during the experiment. The control and experimental animals were provided food and drinking water ad libitum. The study was conducted after obtaining permission from institutional animal ethics committee.

\section{Experiment}

The animals were divided into control and test groups and each group consisted of 6 animals. Group 1 animals served as control and were injected intraperitoneally with distilled water (vehicle). Groups 2, 3, 4 and 5 constituted test groups and were injected intraperitoneally with ceftriaxone. Groups 2 and 3 were administered $100 \mathrm{mg} / \mathrm{kg}$ BW and groups 4 and 5 were administered 200mg/kg BW ceftriaxone respectively. All animals were provided standard pellet diet and water ad libitum. All animals were sacrificed by cervical dislocation for the assessment of micronuclei. Bone marrow was harvested at $24 \mathrm{hr}$ and 48 hr time point.

\section{In vivo micronucleus test}

It was conducted as per the procedure of Schmid. ${ }^{10-12}$ Needle was inserted into the upper end of femur and $0.5 \mathrm{ml}$ of fetal bovine serum was injected into the lower epiphyseal end. Collected bone marrow samples were centrifuged at $1000 \mathrm{rpm}$ for $8 \mathrm{~min}$.
Film was prepared by smearing the supernatant and then dried. Smear was fixed in absolute methanol for $10 \mathrm{~min}$. Slides were stained with May-Grunwald's stain in phosphate buffer (1:1, pH 6.8) followed by Giemsa staining and kept for $30 \mathrm{~min}$. Slides were washed multiple times with distilled water and air-dried. Slides were coded and analysed for micronuclei. The incidence of micronuclei in polychromatic erythrocytes (MnPCE) was noted per 2000 polychromatic erythrocytes (PCE) in each slide. The ratio of polychromatic to normochromatic erythrocytes (NCE) was estimated for every 500 erythrocytes in each slide. ${ }^{12-15}$

\section{Statistical analysis}

Results were expressed as mean \pm SD. Chromosomal damage was measured as percentage of micronucleated polychromatic erythrocytes per 2000 PCE (\% MnPCE). Bone marrow cytotoxicity was expressed as PCE:NCE ratio. Data were analyzed using ANOVA followed by Dunnett's test. $\mathrm{p}<0.05$ was considered as significant. A compound was considered genotoxic if a statistically significant increase in the number of micronucleated PCEs (MnPCE) was found in comparison to the vehicle control. Data was analysed by GraphPad prism version 6.05.

\section{RESULTS}

The $\%$ micronuclei induced after administration of ceftriaxone at $100 \mathrm{mg} / \mathrm{kg} \mathrm{BW}$ and $200 \mathrm{mg} / \mathrm{kg} \mathrm{BW}$ at $24 \mathrm{hr}$ and $48 \mathrm{hr}$ harvest time and PCE:NCE ratio were statistically analyzed. The results from the various test groups were compared with the control group. The results of the in vivo micronucleus tests are presented in Table 1.

Table 1: Effect of ceftriaxone on mice bone marrow (Micronucleus test).

\begin{tabular}{|llll|}
\hline $\begin{array}{l}\text { Treatment } \\
\text { group }\end{array}$ & $\begin{array}{l}\text { Harvest } \\
\text { time(hrs) }\end{array}$ & $\begin{array}{l}\% \mathrm{MnPCE} \\
(\mathrm{Mean} \pm \mathrm{SD})\end{array}$ & $\begin{array}{l}\text { PCE: NCE } \\
(\mathrm{Mean} \pm \mathrm{SD})\end{array}$ \\
$\begin{array}{l}\text { Group 1: } \\
\text { Distilled } \\
\text { water }\end{array}$ & $24 \mathrm{hrs}$ & $0.16 \pm 0.04$ & $1.01 \pm 0.01$ \\
\hline $\begin{array}{l}\text { Group 2: } \\
\text { Ceftriaxone } \\
\text { (100 mg/kg) }\end{array}$ & $24 \mathrm{hrs}$ & $0.22 \pm 0.01^{\mathrm{NS}}$ & $1.04 \pm 0.04^{\mathrm{NS}}$ \\
\hline $\begin{array}{l}\text { Group 3: } \\
\text { Ceftriaxone } \\
(100 \mathrm{mg} / \mathrm{kg})\end{array}$ & $48 \mathrm{hrs}$ & $0.23 \pm 0.02^{\mathrm{NS}}$ & $1.05 \pm 0.02^{\mathrm{NS}}$ \\
\hline $\begin{array}{l}\text { Group 4: } \\
\text { Ceftriaxone } \\
(200 \mathrm{mg} / \mathrm{kg})\end{array}$ & $24 \mathrm{hrs}$ & $0.26 \pm 0.03^{\mathrm{NS}}$ & $1.04 \pm 0.01^{\mathrm{NS}}$ \\
\hline $\begin{array}{l}\text { Group 5: } \\
\text { Ceftriaxone } \\
(200 \mathrm{mg} / \mathrm{kg})\end{array}$ & $48 \mathrm{hrs}$ & $0.31 \pm 0.01^{\mathrm{NS}}$ & $1.06 \pm 0.02^{\mathrm{NS}}$ \\
\hline
\end{tabular}

Data expressed as mean \pm SD. $\mathrm{n}=6$; *p $<0.05$, ** $\mathrm{p}<0.01$, $* * * \mathrm{p}<0.001$ (compared with control), NS- not significant

In the present study, ceftriaxone at the dose of $100 \mathrm{mg} / \mathrm{kg}$ BW increased the \% MnPCE after $24 \mathrm{hr}$ and $48 \mathrm{hr}$ as 
compared to control animals but this was not statistically significant $(\mathrm{P}>0.05)$ (Table 1 and Figure 1). At the dose of $200 \mathrm{mg} / \mathrm{kg} \mathrm{BW}$ also there was no statistically significant increase in the \% MnPCE after $24 \mathrm{hr}$ and $48 \mathrm{hr}$ as compared to control group. ( $\mathrm{P}>0.05)$ (Table 1 and Figure 1) The PCE:NCE ratio was increased in ceftriaxone treated animals (dose $100 \mathrm{mg} / \mathrm{kg} \mathrm{BW}$ and $200 \mathrm{mg} / \mathrm{kg} \mathrm{BW}$ after 24 $\mathrm{hr}$ and $48 \mathrm{hr}$ ) as compared to control animals but this was not statistically significant $(\mathrm{P}>0.05)$ (Table 1 and Figure 2).

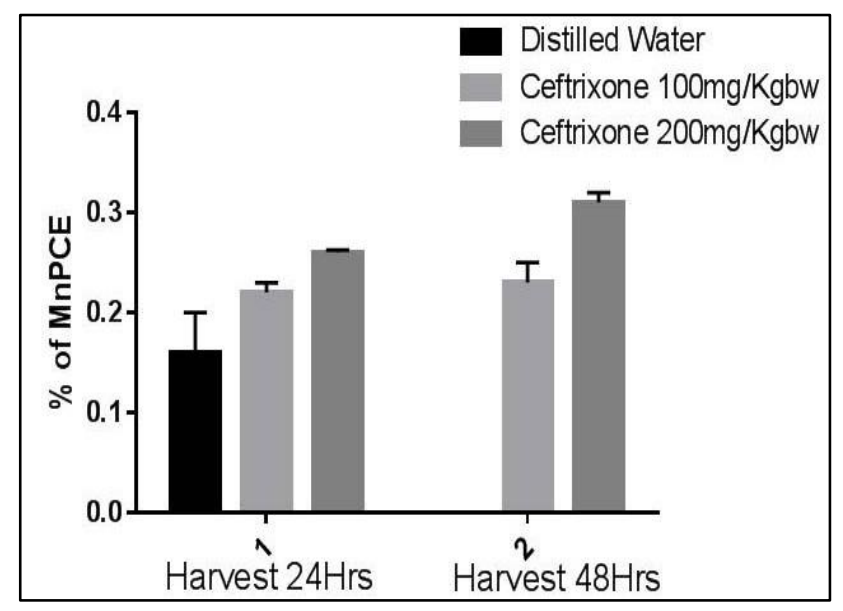

Figure 1: Percentage of MnPCE per $2000 \mathrm{PCE}$ in normal and experimental animals in each group.

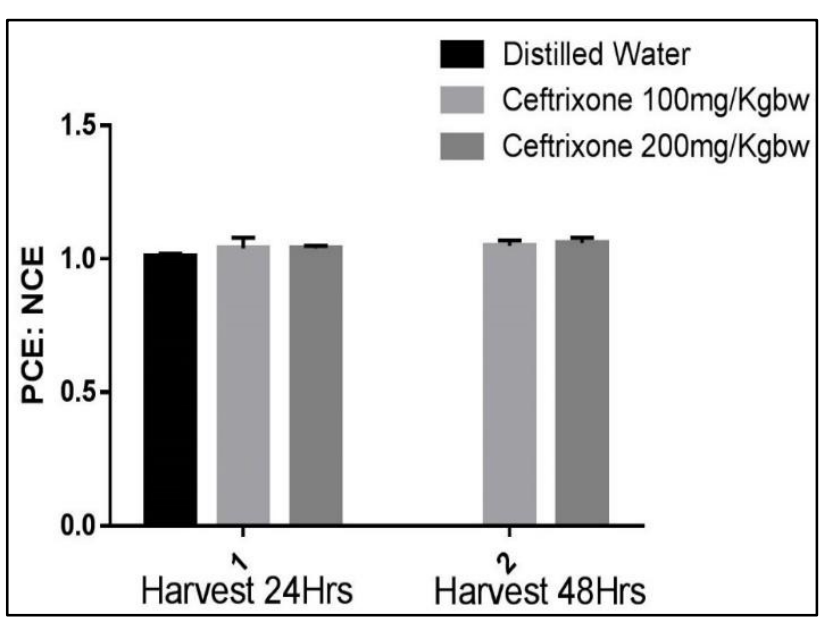

Figure 2: PCE:NCE ratios in normal and experimental animals in each group.

\section{DISCUSSION}

Genotoxicity screening of newly discovered drugs is mandatory. But genotoxic screening of already introduced drugs is also essential. Genotoxicity tests include the Ames test, micronucleus test, comet assay and test for choromosomal aberrations in human lymphocytes cultured in vitro. ${ }^{15}$

Among these tests, the in vivo micronucleus test is one of the primary genotoxicity assays recommended by regulatory agencies internationally for the assessment of product safety. In vivo micronucleus test detects chemicals causing chromosome breaking effects. Micronucleus test is a well-recognized indicator of structural and numerical chromosomal damages, resulting from acentric chromosome fragments or lagging whole chromosome(s) which fail to incorporate into daughter nuclei following nuclear division. ${ }^{16,17}$ Micronucleus formation can also result from lack of centromere or centromeric damage and defect in the cytokinesis. ${ }^{18}$

It is essential to screen the newer as well as currently used drugs for their mutagenic and genotoxic potential as many frequently used drugs tested positive in one of the genotoxicity tests. In previous studies, several cephalosporins like cefixime, cefaclor, cefadroxil, cefotaxime was found to induce chromosomal aberrations. However, there are only limited reports available about the mutagenic potential of ceftriaxone. Hence, in the present study, the mutagenic and genotoxic potential of ceftriaxone at the dose of $100 \mathrm{mg} / \mathrm{kg} \mathrm{BW}$ and $200 \mathrm{mg} / \mathrm{kg} \mathrm{BW}$ was screened by micronucleus test in mice at $24 \mathrm{hr}$ and $48 \mathrm{hr}$ harvest time.

In micronucleus test, genotoxicity is indicated by statistically significant increase in the percentage of MnPCEs (\% MnPCE) in the test group as compared to the control group. Inhibition of cell multiplication in the bone marrow indicates the cytotoxicity of test compound. Bone marrow cytotoxicity is generally indicated by dose related decrease in the fraction of immature erythrocytes.

Young mice were used in the present study because they have high proliferative activity as well as low fat content which are favourable for getting better quality preparations. An increase in the percentage of micronucleated polychromatic erythrocytes (MnPCEs) in treatment group is an indication of induced chromosomal damages. Decrease in PCE:NCE ratio as a result of either direct cytotoxicity or micronuclei formation and heavy DNA damages leads to cell death or apoptosis. ${ }^{18}$

Intraperitonial administration of ceftriaxone at the dose of $100 \mathrm{mg} / \mathrm{kg}$ and $200 \mathrm{mg} / \mathrm{kg} \mathrm{BW}$ at $24 \mathrm{hr}$ and $48 \mathrm{hr}$ harvest time did not increase the percentage of micronuclei significantly as compared to control animal. Ceftriaxone at both the doses and same harvest times did not decrease the PCE/NCE ratio significantly as compared to the control (Table 1). This indicates that ceftriaxone does not have genotoxic potential at these doses. This is in contrast to the study done by Metović et al, where ceftriaxone has demonstrated genotoxic, cytostatic and cytotoxic activity in human lymphocyte culture. ${ }^{19}$

Tanyildizi et al, also reported that ceftriaxone induced an impairment of ram sperm in their study. ${ }^{20}$ These differences may be because of different methods used for genotoxicity screening. Hence further studies are required to confirm the genotoxic potential of ceftriaxone and the mechanism of this effect. From the results of the present 
study it can be concluded that ceftriaxone at a dose of $100 \mathrm{mg} / \mathrm{kg}$ and $200 \mathrm{mg} / \mathrm{kg}$ does not possess genotoxic potential in in vivo mice micronucleus test.

\section{ACKNOWLEDGEMENTS}

Authors would like to thank Dr. Kolanjiappan Kaliyaperumal, for his support during study.

\section{Funding: No funding sources}

Conflict of interest: None declared

Ethical approval: The study was approved by the Institutional Ethics Committee

\section{REFERENCES}

1. William A Petri, Jr. Penicillins, cephalosporins, and other $\beta$-lactam antibiotics. In: Brunton LL, Chabner BA, Knollman BC. Goodman and Gilman's The Pharmacological basis of therapeutics; $12^{\text {th }}$ edition; New York, Mc Graw Hill Companies Inc.; 2011;14771504.

2. Satoskar RS, Rege NN, Tripathi RK, Bhandarkar SD. Antibiotics effective against both gram positive and gram negative organisms. In: Pharmacology and pharmacotherapeutics, 25 $5^{\text {th }}$ Edition; Mumbai, Elsevier; 2017;693-699.

3. Tripathi KD. Beta lactam antibiotics. In: Essential of medical pharmacology, $8^{\text {th }}$ Edition, New Delhi, Jaypee brothers medical publishers(P) Ltd.; 2018;766-783.

4. Snyder RD, Green JW. A review of the genotoxicity of marketed pharmaceuticals. Mutation Research/Reviews in Mutation Research. 2001 May 31;488(2):151-69.

5. Puli LK, Patil PA. Genotoxic evaluation of morphine, buprenorphine, pentazocine, and noscapine by micronucleus and comet assay in albino mice. Ind $\mathbf{J}$ Pharmacol. 2007 Nov 1;39(6):265.

6. Jena GB, Kaul CL, Ramarao P. Regulatory requirements and $\mathrm{ICH}$ guidelines on carcinogenicity testing of pharmaceuticals: A review on current status. Ind J Pharmacol. 2005 Jul 1;37(4):209.

7. Sahu R, Divakar G, Divakar K. In vivo rodent micronucleus assay of Gmelina arborea roxb (gambhari) extract. J Advanced Pharmaceut Tech Res. 2010 Jan;1(1):22-9.

8. Istifli ES, Topaktaş M. In vitro genotoxicity and cytotoxicity of a particular combination of pemetrexed and cefixime in human peripheral blood lymphocytes. Springer Plus. 2015 Dec;4(1):35.
9. Fahmy MA, Diab KA. In vivo genotoxicity studies of cefotaxime. Cytologia. 2009 Dec 30;74(4):417-25.

10. Schmid W. The micronucleus test. Mutat Res. 1975;31:9-15.

11. Sahoo HB, Patro SK, Sagar R, Santani DD. Mutagenic evaluation and spectroscopic characterization of flavonoidal fraction of Apium leptophyllum (Pers.) fruit. Int J Nutr Pharmacol Neu Disea. 2015 Apr $1 ; 5(2): 82$.

12. Health Effect Test Guidelines. 1998. Mamalian erythrocyte micronucleus test, OPPTS 870, 5395 United States Office of Prevention, Pesticides and Toxic Substances Environmental Protection Agency (7101). Available at: http://www.epa.gov/epahome/research.htm.

13. Shahrim Z, Baharuddin PJ, Yahya NA, Muhammad H, Bakar RA, Ismail Z. The in vivo rodent micronucleus assay of Kacip Fatimah (Labisia pumila) extract. Trop Biomed. 2006 Dec 1;23:214-9.

14. Krishna G, Hayashi M. In vivo rodent micronucleus assay: protocol, conduct and data interpretation. Mutation Research. 2000 Nov 20;455(1):155-66.

15. Mohamed SA, Upreti S, Rajendra SV, Dang R. Genotoxicity: Mechanisms, Testing Guidelines and Methods. Glob J Pharmaceut Sci. 2017;1(5).

16. Leme DM, Marin-Morales MA. Allium cepa test in environmental monitoring: a review on its application. Mutation Research/Reviews in Mutation Research. 2009 Aug 31;682(1):71-81.

17. El-Rahim AH, Hafiz NA. Investigation on the protective effect of Grape seed and Linseed oils against ciclophosphamide induced genotoxicity in mice. Global Veterinaria. 2009;3(5):377-82.

18. Asita AO, Molise T. Antimutagenic effects of red apple and watermelon juices on cyclophosphamideinduced genotoxicity in mice. African $\mathrm{J}$ Biotech. 2011;10(77):17763-8.

19. Metović A, Mušanović J. Analysis of genotoxicity of ceftriaxone in human lymphocyte cultures. Eur $\mathbf{J}$ Biomed Pharmaceut Sci. 2017; 4 (6): 31-35.

20. Tanyıldızı S, Türk G. The effects of diminazene aceturate and ceftriaxone on ram sperm. Theriogenol. 2004 Jan 15;61(2-3):529-35.

Cite this article as: Dayana K, Manasa MR.

Genotoxic evaluation of ceftriaxone by in vivo micronucleus test in albino mice. Int $\mathbf{J}$ Basic Clin Pharmacol 2018;7:1705-8. 